\title{
Expression and significance of CHIP in canine mammary gland tumors
}

\author{
Huanan WANG ${ }^{1,2)}$ Xu YANG ${ }^{1)}$, Yipeng JIN ${ }^{1)}$, Shimin PEI ${ }^{1)}$, Di ZHANG ${ }^{1)}$, Wen $\mathrm{MA}^{1)}$, Jian HUANG ${ }^{1)}$, Hengbin QIU ${ }^{1)}$, \\ Xinke $\mathrm{ZHANG}^{1)}$, Qiuyue JIANG ${ }^{1)}$, Weidong $\mathrm{SUN}^{1)}$, Hong $\mathrm{ZHANG}^{1)}$ and Degui $\mathrm{LIN}^{1) *}$ \\ ${ }^{1)}$ The Clinical Department, College of Veterinary Medicine, China Agricultural University, Beijing 100193, P.R. China \\ ${ }^{2)}$ Department of Veterinary Medicine, College of Animal Sciences, Zhejiang University, Hangzhou 310012, P.R. China
}

(Received 18 September 2014/Accepted 2 June 2015/Published online in J-STAGE 9 July 2015)

ABSTRACT. CHIP (Carboxy terminus of Hsc70 Interacting Protein) is an E3 ubiquitin ligase that can induce ubiquitination and degradation of several oncogenic proteins. The expression of CHIP is frequently lower in human breast cancer than in normal breast tissue. However, the expression and role of CHIP in the canine mammary gland tumor (CMGT) remain unclear. We investigated the potential correlation between CHIP expression and mammary gland tumor prognosis in female dogs. CHIP expression was measured in 54 dogs by immunohistochemistry and real-time RT-PCR. CHIP protein expression was significantly correlated with the histopathological diagnosis, outcome of disease and tumor classification. The transcriptional level of CHIP was significantly higher in normal tissues $(P=0.001)$ and benign tumors $(P=0.009)$ than it in malignant tumors. CHIP protein expression was significantly correlated with the transcriptional level of $C H I P$ $(P=0.0102)$. The log-rank test survival curves indicated that patients with low expression of CHIP had shorter overall periods of survival than those with higher CHIP protein expression $(P=0.050)$. Our data suggest that CHIP may play an important role in the formation and development of CMGTs and serve as a valuable prognostic marker and potential target for genetic therapy.

KEY WORDS: canine mammary gland tumor, CHIP, immunohistochemistry, prognosis, RT-PCR

doi: 10.1292/jvms.14-0484; J. Vet. Med. Sci. 77(11): 1465-1471, 2015

Mammary gland tumors are the most common tumors in female dogs and women [3, 31, 33]. Approximately half of all canine mammary gland tumors are malignant $[5,6]$, with a high rate of recurrence following surgical excision $[28,30]$. It is crucial to find appropriate biomarkers to define the cancer risks, contribute to tumor detection and diagnosis, predict outcomes of the disease and assist in surveillance for disease recurrence. So far, many biomarkers, such as mutant p53 and PTEN, of tumorigenesis have been found for canine mammary gland tumors (CMGTs) [22, 31]. Recently, the CHIP (Carboxy terminus of Hsc70 interacting protein) gene has come to be thought of as a tumor suppressor gene with prognostic significance. When examined in humans, CHIP expression has also been reported to be decreased in human mammary and gastric cancer [29, 37].

CHIP, which is encoded by the STUB1 gene, is an E3 ubiquitin ligase that induces ubiquitination $[7,10]$ and degradation of several oncogenic proteins, including mutant P53 $[25,36]$, estrogen receptor A [11], c-ErbB2/neu [40], Dbl [19], Smad3 [39], hypoxia inducible factor 1a [4], Runx1 [34], Met receptor [16] and SRC-3 [18]. It could also act as a suppressor of tumor metastasis. CHIP possesses a tetratricopeptide repeat (TPR) domain, which interacts with the molecular chaperones Hsc/Hsp70 and Hsp90, and a carboxyl-terminal U-box domain with E3 ubiquitin ligase activity,

*Correspondence to: Lin, D., The Clinical Department, College of Veterinary Medicine, China Agricultural University, Beijing 100193, P.R. China. e-mail: csama@sina.com

(C)2015 The Japanese Society of Veterinary Science

This is an open-access article distributed under the terms of the Creative Commons Attribution Non-Commercial No Derivatives (by-nc-nd) License $<$ http://creativecommons.org/licenses/by-nc-nd/3.0/>. which functions as a link between the chaperone and proteasome systems [2]. In humans, there is substantial evidence showing that CHIP functions as a tumor suppressor. Some recent studies indicate that the abundance of CHIP inhibits metastatic potential, and knockdown of CHIP increased the microvessel density in human breast and gastric cancers $[15,18,29,37]$. However, the function and prognostic role of CHIP expression in CMGTs have not been well studied. The aim of our study was to assess CHIP expression and its possible use as a prognostic marker in CMGTs.

\section{MATERIALS AND METHODS}

Animal tissue and histological classification: All of the mammary gland tumor specimens including five normal mammary glands were collected from the Veterinary Teaching Hospital of China Agricultural University between July 2009 and September 2011. Mammary gland tumors were surgically removed from 49 female dogs of different breeds aged between 2 and 17 years old (mean=10 years old). Normal mammary tissues were obtained from five healthy experimental dogs, and the procedures were approved by the Animal Welfare Committee of the Department of Clinical Veterinary Medicine of China Agricultural University. Two portions of each mammary gland were collected from each dog. Samples used in RT-PCR assay were frozen immediately in liquid nitrogen after surgical removal. Samples for immunohistochemistry (IHC) were fixed in 10\% neutral buffered formalin and were embedded in paraffin wax by standard histological methods. Tissue blocks were sectioned at $3 \mu \mathrm{m}$ and stained with hematoxylin and eosin (HE). Serial $3 \mu \mathrm{m}$ sections were used for IHC. Each section was evaluated by three independent pathologists blinded to each other. 
The histological type was assessed based on classification and grading of canine mammary gland tumors in 2011 [14]. Histological grading of mammary carcinomas was assessed according to a previously described method of classification $[9,20]$. The canine mammary gland carcinomas were classified as simple, solid, complex, spindle cell or sarcoma.

Overall survival time was the period between surgery and death due to the malignant tumor. Dogs dying of non-tumorrelated causes were removed from the study. Follow-up data were obtained by consulting the medical records in the hospital and by telephone contact with the owners of the animals.

Immunohistochemistry staining: Three-micrometer-thick sections were first dewaxed in xylene and rehydrated in graded alcohols. The slides were immersed in 3\% hydrogen peroxidase for $20 \mathrm{~min}$ to quench endogenous peroxidase activity. They were then placed into jars containing citric acid buffer to unveil the antigen, and the retrieval was performed in a microwave oven at $98^{\circ} \mathrm{C}$ for $20 \mathrm{~min}$. After the jars were cooled to room temperature at $25^{\circ} \mathrm{C}$, the slides were covered with $10 \%$ goat serum in PBS for $30 \mathrm{~min}$ at room temperature. After blocking nonspecific binding, the slides were incubated with the primary antibody overnight at $4^{\circ} \mathrm{C}$ in a moist chamber. Rabbit polyclonal anti-CHIP (Anti-STUB1 polyclonal antibody, Abcam, Cambridge, U.K.) used as the primary antibody was diluted 1:200 with PBS. After being thoroughly rinsed three times in PBST for 10 min each, the slides were incubated with the secondary antibody (HRPLabeled anti-rabbit antibody, Santa Crus Biotechnology, Dallas, TX, U.S.A.) according to the manufacturer's instructions. The slides were thoroughly washed 3 times again, and then, the color was developed with 3, 3'-diaminobenzidine tetrahydrochloride (DAB kit, ZSGB-BIO, Beijing, P.R. China) for $10 \mathrm{~min}$. The sections were counterstained with hematoxylin, dehydrated with graded alcohol and xylene, and mounted with a cover slip. Negative controls were obtained by replacing the primary antibody with normal rabbit serum.

Assessment of immunohistochemistry: CHIP expression was evaluated independently by three pathologists blinded to the clinical data. A semiquantitative immunoreactivity score was applied in this text, as reported elsewhere [38, 41]. The intensity of immunostaining was scored on a scale of 0-3 (0, negative immunostaining; 1 , weak immunostaining; 2 , moderate immunostaining; and 3 , strong immunostaining). The percentage of immunoreactive cells was scored as $1(0-25 \%), 2(26-50 \%), 3(51-75 \%)$ or $4(76-100 \%)$. Multiplication of both resulted in an immunoreactive score (IRS) ranging from 0 to 12 for each tumor. Additionally, specimens with an IRS $\leq 4$ and those with an IRS $>4$ were classified as having low and high expression of CHIP protein, respectively $[38,41]$. For accurate analysis, the number of immune-labeled cells was assessed based only on the number of positive cells among the neoplastic cells within 20 selected fields.

RNA isolation and cDNA synthesis: RNA isolation was performed with the use of RNAiso Plus (Takara; Dalian, Liaoning, P.R. China) according to the manufacturer's instructions (Takara; code No. 9108/9109). Approximately 1 $\mu \mathrm{g}$ of total RNA was reversely transcribed to cDNA using avian myeloblastosis virus (AMV) reverse transcriptase and oligo (dT) primers (Takara).

Real-time RT-PCR: The primers for real-time RT-PCR were designed using the Primer 5.0 software. The primers were 5' CCT ACC TCA CTC GGC TTA TTG T 3' (forward) and 5' TCG TCC ACC TGG GAG AAA A 3' (reverse) for $C H I P$ and $5^{\prime}$-ATA TCG CTG CGC TTG TGG TC -3' (forward) and 5'- CCG TGC TCA ATG GGG TAC TTC-3' (reverse) for $\beta$-actin; $\beta$-actin mRNA for each sample was used as an internal control, and the $\mathrm{Ct}$ value was normalized to $\beta$-actin mRNA for each sample.

The transcriptional level of CHIP was determined in triplicate by real-time RT-PCR using an ABI Prism 7500 Sequence Detection System (Applied Biosystems, Foster City, CA, U.S.A.). Briefly, the reaction mixture contained $2 \mu l$ of cDNA template, $10 \mu l$ of DNA SYBR Green qPCR mix (Takara) and $1 \mu l$ of each primer. The RT-PCR protocol was as follows: initial denaturation at $95^{\circ} \mathrm{C}$ for $30 \mathrm{sec}$; denaturation at $95^{\circ} \mathrm{C}$ for $10 \mathrm{sec}$,annealing at $60^{\circ} \mathrm{C}$ for $30 \mathrm{sec}$, extension at $72^{\circ} \mathrm{C}$ for $30 \mathrm{sec}$ and fluorescent data acquisition at $72^{\circ} \mathrm{C}$ for $1 \mathrm{~min}$ (36 cycles), and final extension at $72^{\circ} \mathrm{C}$ for $5 \mathrm{~min}$ to form full duplex DNA. The specificity of the amplified products was checked by a melting curve analysis following the completion of PCR. The melting curve protocol used was heating from $60^{\circ} \mathrm{C}$ to $95^{\circ} \mathrm{C}$ at a rate of $0.3^{\circ} \mathrm{C}$ for 1 min per step.

Statistical analysis: Statistical analysis of the data was performed using the GraphPad Prism 5.0 or IBM SPSS statistics 20 computer software. Statistically significant variations of noncontiguous variables between different groups were determined using the chi-square test. The survival curve was analyzed using the log-rank test method. Multiple comparisons of continuous variables were analyzed using the LSD method. $P<0.05$ was considered to indicate a statistical difference, and $P<0.01$ was considered to indicate a significant difference.

\section{RESULTS}

Expression of CHIP protein in canine mammary gland tissues by immunohistochemistry: The histological types of 54 canine mammary gland tissues and their CHIP expression levels are summarized in Table 1. According to the canine mammary tumor classification in 2011 [14], 41 of the 54 cases were canine malignant mammary gland tumors, belonging to the following histopathology types: simple carcinoma $(29.2 \%)$, solid carcinoma $(46.3 \%)$, complex carcinoma (12\%), spindle cell carcinoma $(7.3 \%)$ and sarcoma $(5.2 \%)$. Benign tumors were confirmed in 8 cases. There were also 5 normal mammary tissues. Immunohistochemical staining of CHIP protein in canine mammary gland tissues (Fig. 1) showed that expression of CHIP protein was mainly localized in the cytoplasm but was occasionally present in the nucleus. We also found that CHIP expression in myoepithelial cells was low in our samples. CHIP protein is abundant in normal mammary tissue, and the cell type showing a positive reaction was the luminal epithelial cell (Fig. 1A). The expression of CHIP could be detected in most of the benign tumors (Fig. 1B) and in a low percentage of carcinomas 
Table1. Histopathological diagnosis, immunohistochemistry of CHIP, outcome of disease, overall survival time and grade for the 54 dogs

\begin{tabular}{|c|c|c|c|c|c|}
\hline Sample & HD & $\mathrm{IHC}$ & Outcome & OS & Grade \\
\hline 1 & Carcinosarcoma & Low & Death-metastasis & $<6$ months & II \\
\hline 2 & Fibrosarcoma & Low & Death & $>18$ months & II \\
\hline 3 & Complex carcinoma & Low & Death-metastasis & $<6$ months & II \\
\hline 4 & Spindle cell carcinoma & Low & Alive-recurrence & $>18$ months & II \\
\hline 5 & Solid carcinoma & Low & Death-recurrence & 6 to 18 months & III \\
\hline 6 & Solid carcinoma & Low & Alive & $>18$ months & II \\
\hline 7 & Spindle cell carcinoma & Low & Alive & $>18$ months & II \\
\hline 8 & Solid carcinoma & Low & Death & 6 to 18 months & III \\
\hline 9 & Solid carcinoma & Low & Death-metastasis & $<6$ months & III \\
\hline 10 & Complex carcinoma & Low & Alive & $>18$ months & II \\
\hline 11 & Tubulopapillary carcinoma & Low & Death-metastasis & $<6$ months & III \\
\hline 12 & Spindle cell carcinoma & Low & Alive & $>18$ months & II \\
\hline 13 & Solid carcinoma & Low & Death-recurrence & $>18$ months & II \\
\hline 14 & Tubulopapillary carcinoma & Low & Death & 6 to 18 months & II \\
\hline 15 & Tubulopapillary carcinoma & Low & Death & $>18$ months & II \\
\hline 16 & Tubulopapillary carcinoma & Low & Alive & $>18$ months & I \\
\hline 17 & Solid carcinoma & Low & Death-metastasis & $<6$ months & III \\
\hline 18 & Solid carcinoma & Low & Alive & $>18$ months & II \\
\hline 19 & Solid carcinoma & Low & Death-recurrence & $<6$ months & II \\
\hline 20 & Solid carcinoma & Low & Death-metastasis & $<6$ months & III \\
\hline 21 & Tubulopapillary carcinoma & Low & Alive & $>18$ months & I \\
\hline 22 & Solid carcinoma & Low & Death & $>18$ months & III \\
\hline 23 & Solid carcinoma & Low & Alive & $>18$ months & II \\
\hline 24 & Tubulopapillary carcinoma & Low & Alive & $>18$ months & II \\
\hline 25 & Tubulopapillary carcinoma & Low & Alive & $>18$ months & II \\
\hline 26 & Tubulopapillary carcinoma & Low & Alive & $>18$ months & I \\
\hline 27 & Solid carcinoma & Low & Death-metastasis & $<6$ months & III \\
\hline 28 & Solid carcinoma & Low & Death & $>18$ months & I \\
\hline 29 & Benign & Low & Alive & $>18$ months & \\
\hline 30 & Complex carcinoma & High & Alive & $>18$ months & I \\
\hline 31 & Solid carcinoma & High & Alive & $>18$ months & III \\
\hline 32 & Tubulopapillary carcinoma & High & Alive & $>18$ months & II \\
\hline 33 & Complex carcinoma & High & Alive & $>18$ months & II \\
\hline 34 & Tubulopapillary carcinoma & High & Alive & $>18$ months & II \\
\hline 35 & Solid carcinoma & High & Death-euthanasia & $<6$ months & III \\
\hline 36 & Solid carcinoma & High & Death & 6 to 18 months & II \\
\hline 37 & Tubulopapillary carcinoma & High & Alive & $>18$ months & I \\
\hline 38 & Solid carcinoma & High & Alive & $>18$ months & I \\
\hline 39 & Solid carcinoma & High & Alive & $>18$ months & III \\
\hline 40 & Solid carcinoma & High & Alive & $>18$ months & II \\
\hline 41 & Tubulopapillary carcinoma & High & Alive & $>18$ months & I \\
\hline 42 & Complex carcinoma & High & Death-metastasis & 6 to 18 months & II \\
\hline 43 & Benign & High & Alive & $>18$ months & \\
\hline 44 & Benign & High & Alive & $>18$ months & \\
\hline 45 & Benign & High & Alive & $>18$ months & \\
\hline 46 & Benign & High & Alive & $>18$ months & \\
\hline 47 & Benign & High & Alive & $>18$ months & \\
\hline 48 & Benign & High & Alive & $>18$ months & \\
\hline 49 & Benign & High & Alive & $>18$ month & \\
\hline 50 & Normal & High & & & \\
\hline 51 & Normal & High & & & \\
\hline 52 & Normal & High & & & \\
\hline 53 & Normal & High & & & \\
\hline 54 & Normal & High & & & \\
\hline
\end{tabular}

HD: Histopathological diagnosis, IHC: Immunohistochemistry, OS: Overall survival (the period between surgery and death due to malignant tumor). 

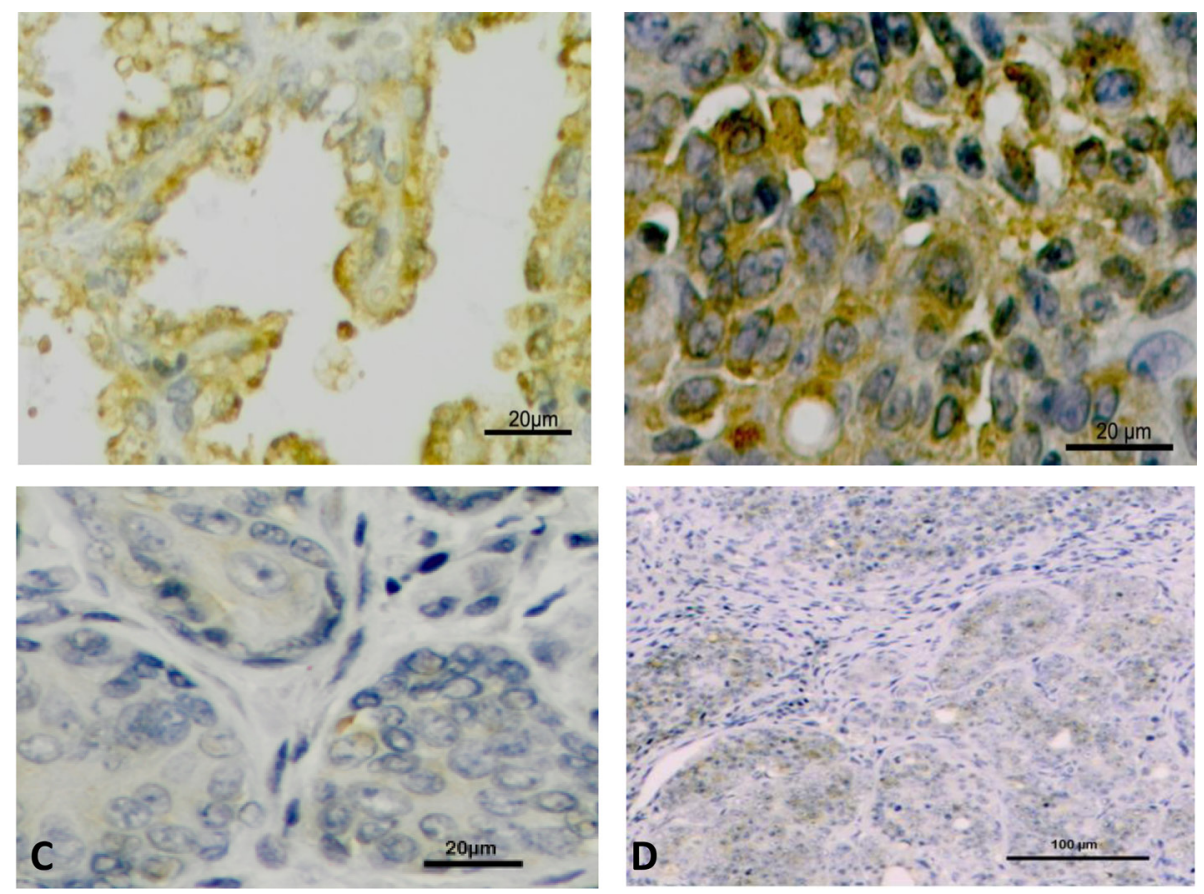

Fig. 1. Sample of immunohistochemical staining of CHIP in CMGT and normal mammary tissue. (A) Normal mammary tissue with an abundance of CHIP protein, (B) Benign tumor with an abundance of CHIP protein, (C) Malignant tumor with low expression of CHIP protein, (D) Complex carcinoma with low expression of CHIP protein.

Table 2. Correlation between histopathological diagnosis and CHIP expression in 49 canine mammary gland tumors

\begin{tabular}{lccc}
\hline \multirow{2}{*}{ Histopathological diagnosis } & \multicolumn{2}{c}{ IHC } & \multirow{2}{*}{$P$} \\
\cline { 2 - 3 } & High & Low & \\
\hline Simple & 4 & 8 & \\
Solid & 6 & 13 & \\
Complex & 3 & 2 & \\
Spindle & 0 & 3 & \\
Sarcoma & 0 & 2 & $0.030^{*}$ \\
Benign & 7 & 1 & \\
All & 20 & 29 & \\
\hline
\end{tabular}

* $\chi^{2}$ test, $P$ value.

Table 3. Correlation between immunostaining and outcome of disease

\begin{tabular}{lccc}
\hline \multirow{2}{*}{ Immunostaining } & \multicolumn{2}{c}{ Outcome } & \multirow{2}{*}{$P$} \\
\cline { 2 - 3 } & Death & Alive & \\
\hline High & 3 & 10 & \\
low & 16 & 12 & $0.034^{*}$ \\
All & 19 & 22 & \\
\hline
\end{tabular}

$\chi^{2}$ test, $P$ value.

(Fig. 1C and 1D). The CHIP protein level was low in $68 \%$ of the malignant tumors $(28 / 41)$ and high in $87 \%$ of the benign tumors $(7 / 8)$. We also found that the CHIP protein level was low in myoepithelial components $(5 / 5)$.

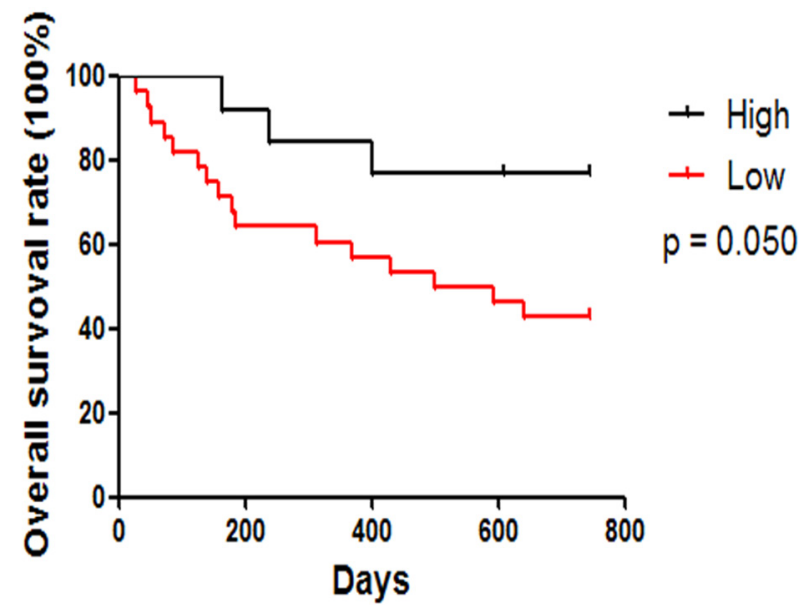

Fig. 3. Log-rank test curves for malignant tumors with high CHIP expression (IHC score $>4$ ) and low CHIP expression (IHC $\leq 4$ ). Dogs with high CHIP expression had longer survival times than those with low CHIP expression $(P=0.050)$.

Correlations between CHIP protein expression levels and clinicopathological variables: The immunohistochemical tests of CHIP demonstrated a significant correlation between the CHIP expression and histopathological diagnosis ( $P=0.007$, Table 2$)$. As described in Table 3, the relationship between outcome and immunostaining was statistically different $(P=0.034)$. The comparative histopathological diagnosis 
Table 4. Correlation between histopathological diagnosis and overall survival time for 41 dogs having malignant mammary gland tumors

\begin{tabular}{|c|c|c|c|c|}
\hline \multirow{2}{*}{$\begin{array}{l}\text { Histopathological } \\
\text { diagnosis }\end{array}$} & \multicolumn{3}{|c|}{ Overall survival time in months } & \multirow{2}{*}{$P$} \\
\hline & $<6$ & $6-18$ & $>18$ & \\
\hline Simple & 1 & 1 & 10 & \\
\hline Solid & 6 & 3 & 8 & \\
\hline Complex & 1 & 1 & 3 & \\
\hline Spindle & 0 & 0 & 3 & $0.531 *$ \\
\hline Sarcoma & 1 & 0 & 1 & \\
\hline All & 9 & 5 & 25 & \\
\hline
\end{tabular}

* $\chi^{2}$ test, $P$ value.

and overall survival time did not demonstrate a statistical concordance (Table 4). There were also no correlations between CHIP immunostaining and histological grading (Table 5).

Transcriptional level of CHIP in canine mammary gland tissues by RT-PCR: The transcriptional level of CHIP in normal mammary gland tissues differed significantly from those in malignant tumors $(P=0.001)$, however, no differences were detected between normal and benign tumor tissues $(P=0.284)$ (Fig. 2A). The transcriptional level of CHIP was significantly different between benign and malignant tumors $(P=0.009)$ (Fig. 2A). There was also a good concordance between the CHIP transcription level detected by RT-PCR and CHIP protein expression examined by immunohistochemistry $(P=0.0102)$ (Fig. 2B).

Association of CHIP protein expression in canine malignant mammary tumors with overall survival: The follow-up time was at least 18 months after tumor resection. Single variable survival analysis showed that CHIP expression was a significant prognostic factor for overall survival $(P=0.050)$ (Fig. 3). Patients with a lower CHIP expression level had a poorer overall survival rate.

\section{DISCUSSION}

Human breast cancer and canine mammary gland carcinoma have the similar epidemiology and clinic pathology. Canine mammary gland carcinomas are the most common life-threatening disease in small animal clinic practice, which has as yet no effective clinical treatment. Therefore, it is important to discover a practical potential treatment target in canine mammary cancer.

CHIP is known to be involved in ubiquitination and degradation of certain oncoproteins, such as NF- $\kappa \mathrm{B}, \mathrm{SRC}-3$ and mutant p53 [17, 18, 25, 32]. Previous research has shown that NF- $\kappa \mathrm{B}$ is a useful prognostic factor for canine mammary gland tumor [24]. It regulates downstream genes, including $I L-6, I L-8, M M P-2, V E G F$ and cyclooxygenase-2, to promote proliferation, survival, angiogenesis and metastasis of tumors $[12,21]$. A previous study in humans also showed that overexpression of CHIP could suppress expression of NF- $\kappa \mathrm{B}$ downstream genes, especially IL-8 [37]. Clinical studies have shown that IL-8 is upregulated in several human malignancies, including melanoma [26], colon cancer [8], non-small cell lung cancer, gastric cancer [23] and breast
Table 5. Correlation between IMC and histological grading

\begin{tabular}{lccc}
\hline \multirow{2}{*}{ Histological grading } & \multicolumn{2}{c}{ IHC } & \multirow{2}{*}{$P$} \\
\cline { 2 - 3 } & High & Low & \\
\hline I & 4 & 4 & \\
II & 6 & 16 & \\
III & 3 & 8 & $0.4639^{*}$ \\
All & 13 & 28 & \\
\hline
\end{tabular}

* $\chi^{2}$ test, $P$ value.

carcinoma [34], and is also linked to tumor angiogenesis, metastatic phenotype and overall poor prognosis [35]. SRC3 is a steroid receptor coactivator, and SRC-3 overexpression has been detected in multiple cancers, including breast, gastric and prostate cancers $[1,13,37]$. In breast cancer, SRC-3 overexpression is associated with high levels of HER2, tamoxifen resistance and poor overall survival time $[13,27]$. P53 is one of the most intensively studied tumorsuppressor proteins. It has been clarified that the mutant p53 proteins can gain new functions favoring the maintenance, insurgence, spreading and chemoresistance of malignant tumors $[25,36]$. To elucidate whether or not a decrease in CHIP protein amount is associated with malignant proliferation of canine secretory epithelial neoplastic cells, a further study, e.g, analysis of CHIP degraded oncoproteins by immunostaining or western blotting, is needed.

Wang et al. reported that CHIP is a novel suppressor of tumor angiogenesis in human gastric cancer [37]. Studies of xenografts in nude mice indicated that gastric cancers overexpressing CHIP could reduce blood vessel formation, suggesting that CHIP may suppress angiogenesis in the tumor [37]. In addition, overexpression of CHIP also suppresses cell adhesion and invasion [37]. Also, Jan et al. found that reduced CHIP expression is related to unfavorable tumor grade, advanced pathological stage, larger tumor size and poor overall survival in breast cancer patients [15]. Taken together, the previous data presented here show that CHIP protein was significantly correlated with cancer progression and was an independent prognostic marker of overall survival in human cancer patients. Nevertheless, there are no studies focusing on CHIP expression and its clinical relevance in canine mammary cancer. In this study, we investigated the clinical relevance of CHIP in the canine mammary gland tumor.

Previous investigations have demonstrated a significant reduction in the transcriptional level of $C H I P$ in a high percentage of human breast cancers versus normal mammary glands and benign mammary tumors and have also reported that the CHIP protein and CHIP gene transcription levels correlate well $[18,29]$. In this article, we reported that the CHIP mRNA level was significantly correlated with the CHIP protein level, suggesting that the CHIP protein level is dependent on the amount of mRNA, which was consistent with the above previous studies.

So far, there are no published studies focusing on the relationship between the CHIP expression level and the histological grading, subtype and outcome in CMGTs. The 


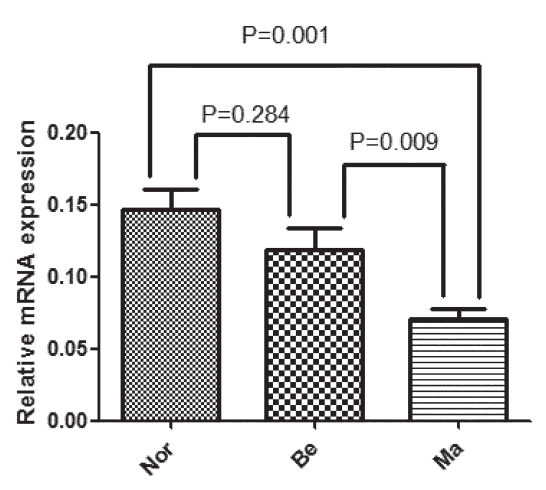

A

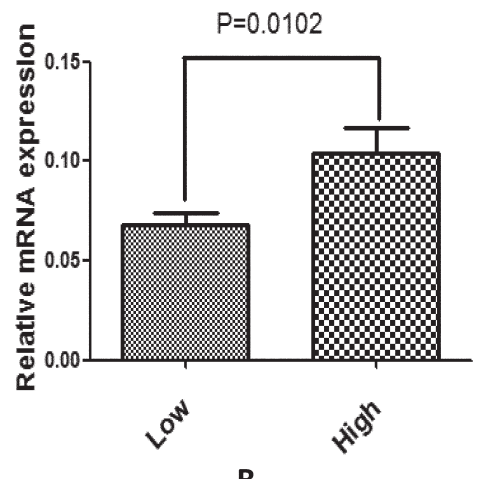

B

Fig. 2. Quantitative analysis of CHIP transcription level in normal mammary tissue, benign tumors and malignant tumors. After CHIP transcription levels were quantitatively analyzed by real-time RT-PCR, relative expression levels (RELs) of CHIP were normalized to $\beta$-actin. The columns and error bars represent the means and their standard errors. (A) Comparisons of RELs of CHIP between normal mammary gland tissues (Nor) and benign (Be) or malignant tumors (Ma) and between $\mathrm{Be}$ and $\mathrm{Ma}$ are shown in the figure. The expression levels in normal mammary tissues were significantly $(P=0.012)$ higher than those in malignant tumors. While no significant difference was observed between normal mammary and benign tissues, a significantly $(P=0.0112)$ higher expression was noted in the benign tumors than in the malignant tumors. (B) Comparisons of RELs of CHIP in mammary gland tumors with different CHIP protein expression levels. The CHIP gene amplification levels of tumors with high expression of CHIP protein are significantly higher than those of tumors with low expression of CHIP protein $(P=0.0102)$.

relation between histological grading and CHIP expression in CMGTs is not with that found in human studies, but the relation between CHIP protein expression and subtype shows statistical concordance, which is consistent with human research. A shorter overall survival was observed, which was significantly associated with low CHIP expression in CMGTs in this study, and similar findings have been observed in human breast cancer.

To our knowledge, this is the first study describing CHIP protein expression analysis in CMGTs. The finding of low expression of CHIP protein in the canine mammary carcinoma and its possible role in the prognosis of this disease are clinically relevant. Moreover, agents with CHIP-enhancing activity might provide an effective strategy for treatment of breast cancer for both dogs and humans, and such agents merit further investigation.

ACKNOWLEDGMENTS. Thanks are due to Jun Dong and Jiangyan Qu for equipment and technical assistance. We also thank Fred Bogott, M.D., Ph.D., at Mayo Clinic, Rochester, MN, U.S.A. for his excellent English editing of this manuscript. We also thank Lei Wang, Ph.D., at Hormel Institute, University of Minnesota, Rochester, MN, U.S.A., for his professional help with IHC. This work was supported by a research grant (No. 31372489) from the National Natural Science Foundation of China.

\section{REFERENCES}

1. Anzick, S. L., Kononen, J., Walker, R. L., Azorsa, D. O., Tanner, M. M., Guan, X. Y., Sauter, G., Kallioniemi, O. P., Trent, J. M. and Meltzer, P. S. 1997. AIB1, a novel estrogen receptor co-activator amplified in breast and ovarian cancer. Science 277:
965-968. [Medline] [CrossRef]

2. Ballinger, C. A., Connell, P., Wu, Y., Hu, Z., Thompson, L. J., Yin, L. Y. and Patterson, C. 1999. Identification of CHIP, a novel tetratricopeptide repeat-containing protein that interacts with heat shock proteins and negatively regulates chaperone functions. Mol. Cell. Biol. 19: 4535-4545. [Medline]

3. Benjamin, S. A., Lee, A. C. and Saunders, W. J. 1999. Classification and behavior of canine mammary epithelial neoplasms based on life-span observations in beagles. Vet. Pathol. 36: 423-436. [Medline] [CrossRef]

4. Bento, C. F., Fernandes, R., Ramalho, J., Marques, C., Shang, F., Taylor, A. and Pereira, P. 2010. The chaperone-dependent ubiquitin ligase CHIP targets HIF-1alpha for degradation in the presence of methylglyoxal. PLoS ONE 5: e15062. [Medline] [CrossRef]

5. Brodey, R. S., Goldschmidt, M. H. and Roszel, J. R. 1983. Canine Mammary-Gland Neoplasms. J. Am. Anim. Hosp. Assoc. 19: 61-90.

6. Brunelle, M., Sartin, E. A., Wolfe, L. G., Sirois, J. and Dore, M. 2006. Cyclooxygenase-2 expression in normal and neoplastic canine mammary cell lines. Vet. Pathol. 43: 656-666. [Medline] [CrossRef]

7. Connell, P., Ballinger, C. A., Jiang, J., Wu, Y., Thompson, L. J., Hohfeld, J. and Patterson, C. 2001. The co-chaperone CHIP regulates protein triage decisions mediated by heat-shock proteins. Nat. Cell Biol. 3: 93-96. [Medline] [CrossRef]

8. Cuenca, R. E., Azizkhan, R. G. and Haskill, S. 1992. Characterization of GRO alpha, beta and gamma expression in human colonic tumours: potential significance of cytokine involvement. Surg. Oncol. 1: 323-329. [Medline] [CrossRef]

9. Elston, C. W. and Ellis, I. O. 1991. Pathological prognostic factors in breast cancer. I. The value of histological grade in breast cancer: experience from a large study with long-term follow-up. Histopathology 19: 403-410. [Medline] [CrossRef]

10. Esser, C., Alberti, S. and Hohfeld, J. 2004. Cooperation of molecular chaperones with the ubiquitin/proteasome system. Biochim. Biophys. Acta 1695: 171-188. [Medline] [CrossRef] 
11. Fan, M., Park, A. and Nephew, K. P. 2005. CHIP (carboxyl terminus of Hsc70-interacting protein) promotes basal and geldanamycin-induced degradation of estrogen receptor-alpha. Mol. Endocrinol. 19: 2901-2914. [Medline] [CrossRef]

12. Garkavtsev, I., Kozin, S. V., Chernova, O., Xu, L., Winkler, F., Brown, E., Barnett, G. H. and Jain, R. K. 2004. The candidate tumour suppressor protein ING4 regulates brain tumour growth and angiogenesis. Nature 428: 328-332. [Medline] [CrossRef]

13. Gnanapragasam, V. J., Leung, H. Y., Pulimood, A. S., Neal, D. E. and Robson, C. N. 2001. Expression of RAC 3, a steroid hormone receptor co-activator in prostate cancer. Br. J. Cancer $\mathbf{8 5}$ : 1928-1936. [Medline] [CrossRef]

14. Goldschmidt, M., Pena, L., Rasotto, R. and Zappulli, V. 2011. Classification and grading of canine mammary tumors. Vet. Pathol. 48: 117-131. [Medline] [CrossRef]

15. Jan, C. I., Yu, C. C., Hung, M. C., Harn, H. J., Nieh, S., Lee, H. S., Lou, M. A., Wu, Y. C., Chen, C. Y., Huang, C. Y., Chen, F. N. and Lo, J. F. 2011. Tid1, CHIP and ErbB2 interactions and their prognostic implications for breast cancer patients. J. Pathol. 225: 424-437. [Medline] [CrossRef]

16. Jang, K. W., Lee, J. E., Kim, S. Y., Kang, M. W., Na, M. H., Lee, C. S., Song, K. S. and Lim, S. P. 2011. The C-terminus of Hsp70-interacting protein promotes Met receptor degradation. $J$. Thorac. Oncol. 6: 679-687. [Medline] [CrossRef]

17. Jiang, J. H., Ballinger, C. A., Wu, Y. X., Dai, Q., Cyr, D. M., Hohfeld, J. and Patterson, C. 2001. CHIP is a U-box-dependent E3 ubiquitin ligase - Identification of Hsc70 as a target for ubiquitylation. J. Biol. Chem. 276: 42938-42944. [Medline] [CrossRef]

18. Kajiro, M., Hirota, R., Nakajima, Y., Kawanowa, K., So-Ma, K., Ito, I., Yamaguchi, Y., Ohie, S., Kobayashi, Y., Seino, Y., Kawano, M., Kawabe, Y., Takei, H., Hayashi, S., Kurosumi, M., Murayama, A., Kimura, K. and Yanagisawa, J. 2009. The ubiquitin ligase CHIP acts as an upstream regulator of oncogenic pathways. Nat. Cell Biol. 11: 312-319. [Medline] [CrossRef]

19. Kamynina, E., Kauppinen, K., Duan, F., Muakkassa, N. and Manor, D. 2007. Regulation of proto-oncogenic dbl by chaperone-controlled, ubiquitin-mediated degradation. Mol. Cell. Biol. 27: 1809-1822. [Medline] [CrossRef]

20. Karayannopoulou, M., Kaldrymidou, E., Constantinidis, T. C. and Dessiris, A. 2005. Histological grading and prognosis in dogs with mammary carcinomas: application of a human grading method. J. Comp. Pathol. 133: 246-252. [Medline] [CrossRef]

21. Karin, M., Cao, Y., Greten, F. R. and Li, Z. W. 2002. NF-kappaB in cancer: from innocent bystander to major culprit. Nat. Rev. Cancer 2: 301-310. [Medline] [CrossRef]

22. Lee, C. H., Kim, W. H., Lim, J. H., Kang, M. S., Kim, D. Y. and Kweon, O. K. 2004. Mutation and overexpression of p53 as a prognostic factor in canine mammary tumors. J. Vet. Sci. $\mathbf{5}$ : 63-69. [Medline] [CrossRef]

23. Lee, K. H., Bae, S. H., Lee, J. L., Hyun, M. S., Kim, S. H., Song, S. K. and Kim, H. S. 2004. Relationship between urokinase-type plasminogen receptor, interleukin- 8 gene expression and clinicopathological features in gastric cancer. Oncology 66: 210-217. [Medline] [CrossRef]

24. Mkaouar, L., Endo, Y., Jun, H. X., Lee, S. J., Jaroensong, T., Mochizuki, M., Uchida, K., Nakayama, H., Sasaki, N. and Nakagawa, T. 2012. Relationship between NF-kappaB expression and malignancy of canine mammary gland tumor tissues. J. Vet. Med. Sci. 74: 713-718. [Medline] [CrossRef]

25. Muller, P., Hrstka, R., Coomber, D., Lane, D. P. and Vojtesek, B. 2008. Chaperone-dependent stabilization and degradation of $\mathrm{p} 53$ mutants. Oncogene 27: 3371-3383. [Medline] [CrossRef]

26. Nürnberg, W., Tobias, D., Otto, F., Henz, B. M. and Schadendorf, D. 1999. Expression of interleukin-8 detected by in situ hybridization correlates with worse prognosis in primary cutane- ous melanoma. J. Pathol. 189: 546-551. [Medline] [CrossRef]

27. Osborne, C. K., Bardou, V., Hopp, T. A., Chamness, G. C., Hilsenbeck, S. G., Fuqua, S. A., Wong, J., Allred, D. C., Clark, G. M. and Schiff, R. 2003. Role of the estrogen receptor coactivator AIB1 (SRC-3) and HER-2/neu in tamoxifen resistance in breast cancer. J. Natl. Cancer Inst. 95: 353-361. [Medline] [CrossRef]

28. Owen, L. N. 1979. A comparative study of canine and human breast cancer. Invest. Cell Pathol. 2: 257-275. [Medline]

29. Patani, N., Jiang, W., Newbold, R. and Mokbel, K. 2010. Prognostic implications of carboxyl-terminus of Hsc70 interacting protein and lysyl-oxidase expression in human breast cancer. $J$. Carcinog. 9: 9. [Medline] [CrossRef]

30. Priester, W. A. 1979. Occurrence of mammary neoplasms in bitches in relation to breed, age, tumour type, and geographical region from which reported. J. Small Anim. Pract. 20: 1-11. [Medline] [CrossRef]

31. Qiu, C. W., Lin, D. G., Wang, J. Q., Li, C. Y. and Deng, G. Z. 2008. Expression and significance of PTEN and VEGF in canine mammary gland tumours. Vet. Res. Commun. 32: 463-472. [Medline] [CrossRef]

32. Robinson, P. A. and Ardley, H. C. 2004. Ubiquitin-protein ligases. J. Cell Sci. 117: 5191-5194. [Medline] [CrossRef]

33. Shafiee, R., Javanbakht, J., Atyabi, N., Kheradmand, P., Kheradmand, D., Bahrami, A., Daraei, H. and Khadivar, F. 2013. Diagnosis, classification and grading of canine mammary tumours as a model to study human breast cancer: an Clinico-Cytohistopathological study with environmental factors influencing public health and medicine. Cancer Cell Int. 13: 79. [Medline] [CrossRef]

34. Shang, Y., Zhao, X., Xu, X., Xin, H., Li, X., Zhai, Y., He, D., Jia, B., Chen, W. and Chang, Z. 2009. CHIP functions an E3 ubiquitin ligase of Runx1. Biochem. Biophys. Res. Commun. 386: 242-246. [Medline] [CrossRef]

35. Sparmann, A. and Bar-Sagi, D. 2004. Ras-induced interleukin-8 expression plays a critical role in tumor growth and angiogenesis. Cancer Cell 6: 447-458. [Medline] [CrossRef]

36. Strano, S., Dell'Orso, S., Di Agostino, S., Fontemaggi, G., Sacchi, A. and Blandino, G. 2007. Mutant p53: an oncogenic transcription factor. Oncogene 26: 2212-2219. [Medline] [CrossRef]

37. Wang, S. Y., Wu, X. M., Zhang, J. B., Chen, Y. S., Xu, J., Xia, X. W., He, S., Qiang, F. L., Li, A. P., Shu, Y. Q., Roe, O. D., Li, G. and Zhou, J. W. 2013. CHIP functions as a novel suppressor of tumour angiogenesis with prognostic significance in human gastric cancer. Gut 62: 496-508. [Medline] [CrossRef]

38. Wolff, A. C., Hammond, M. E., Schwartz, J. N., Hagerty, K. L., Allred, D. C., Cote, R. J., Dowsett, M., Fitzgibbons, P. L., Hanna, W. M., Langer, A., Mcshane, L. M., Paik, S., Pegram, M. D., Perez, E. A., Press, M. F., Rhodes, A., Sturgeon, C., Taube, S. E., Tubbs, R., Vance, G. H., Van De Vijver, M., Wheeler, T. M. and Hayes, D. F. 2007. American Society of Clinical Oncology/ College of American Pathologists guideline recommendations for human epidermal growth factor receptor 2 testing in breast cancer. J. Clin. Oncol. 25: 118-145. [Medline] [CrossRef]

39. Xin, H., Xu, X., Li, L., Ning, H., Rong, Y., Shang, Y., Wang, Y., Fu, X. Y. and Chang, Z. 2005. CHIP controls the sensitivity of transforming growth factor-beta signaling by modulating the basal level of Smad3 through ubiquitin-mediated degradation. $J$. Biol. Chem. 280: 20842-20850. [Medline] [CrossRef]

40. Xu, W., Marcu, M., Yuan, X., Mimnaugh, E., Patterson, C. and Neckers, L. 2002. Chaperone-dependent E3 ubiquitin ligase CHIP mediates a degradative pathway for c-ErbB2/Neu. Proc. Natl. Acad. Sci. U.S.A. 99: 12847-12852. [Medline] [CrossRef]

41. Zhang, K., Jiang, L., He, R., Li, B. L., Jia, Z., Huang, R. H and Mu, Y. 2014. Prognostic value of CYP2W1 expression in patients with human hepatocellular carcinoma. Tumour Biol. 35 7669-7673. [Medline] [CrossRef] 